\title{
Quality indicators in nutrition therapy and clinical outcomes in a neonatal intensive care unit
}

\section{Indicadores de qualidade da terapia nutricional e desfechos clínicos em uma unidade de terapia intensiva neonatal}

\author{
Luciana Carla HOLZBACH ${ }^{1}$ [D 0000-0001-8599-8639 \\ Renata Andrade de Medeiros MOREIRA ${ }^{1}$ ID 0000-0001-6096-9145 \\ Renata Junqueira PEREIRA ${ }^{1}$ ID 0000-0001-9487-4013
}

A B S T R A C T

\section{Objective}

To associate quality indicators in nutritional therapy and pre-determined clinical outcomes in a neonatal unit.

\section{Methods}

A total of 81 premature newborns were monitored regarding the time to initiate nutrition therapy, time to meet energy needs, energy and protein adequacy, cumulative energy deficit, adequacy of the nutritional formula and fasting periods; weight gain, the occurrence of necrotizing enterocolitis, mortality and length of stay in the intensive care unit. The data were analyzed with the Statistical Package for the Social Sciences at 5\% significance level.

\section{Results}

The time to start enteral nutrition and the calories infused $/ \mathrm{kg} /$ day were predictors of length of hospital stay $F(2.46)=6.148$; $p=0.004 ; R^{2}=0.211$; as well as the cumulative energy deficit+birth weight+infused calories/ $\mathrm{kg} / \mathrm{day} \quad(\mathrm{F}=3.52 ; p<0.001$; $\left.R^{2}=0.422\right)$; cumulative energy deficit+calories infused/kg/day+fasting time for Enteral Nutrition $(F=15.041 ; p<0.001$; $\left.R^{2}=0.474\right)$ were predictors of weight gain. The time to start enteral nutrition, gestational age and birth weight were inversely associated with the occurrence of necrotizing enterocolitis $(\beta=-0.38 ; \beta=-0.198 ; \beta=-0.002)$. Early enteral nutrition predisposed to mortality $(\beta=0.33)$. Gestational age, birth weight and calories infused/kg/day were inversely related to mortality $(\beta=-0.442 ; \beta=-0.004 ; \beta=-0.08)$.

\footnotetext{
1 Universidade Federal do Tocantins, Direção de Campus Palmas, Curso de Nutrição. Quadra 109 Norte, Av. NS-15, Alcno-14 Bloco Bala I, Plano Diretor Norte, 77001-090, Palmas, TO, Brasil. Correspondence to: R.J. PEREIRA. E-mail: <renatajunqueira@uft.edu.br>.

Article based on thesis by L.C. HOLZBACH entitled "Segurança alimentar e qualidade em terapia nutricional de recém-nascidos pré-termo em UTI neonatal". Universidade Federal do Tocantins; 2017.
}

How to cite this article

Holzbach LC, Moreira RAM, Pereira RJ. Quality indicators in nutrition therapy and clinical outcomes in a neonatal intensive care unit. Rev Nutr. 2021;34:e200213. https://doi.org/10.1590/1678-9865202134e200213 


\section{Conclusion}

Considering the associations between indicators and outcomes, routine monitoring of the time to start enteral nutrition, energy adequacy, energy deficit and fasting time is recommended.

Keywords: Indicators of morbidity and mortality. Necrotizing enterocolitis. Neonatal intensive care units. Nutrition therapy. Premature infant.

\section{R E S U M O}

\section{Objetivo}

Associar indicadores de qualidade em terapia nutricional e desfechos clínicos pré-determinados em uma unidade neonatal.

\section{Métodos}

81 recém-nascidos prematuros foram monitorados quanto ao tempo para início da terapia nutricional, tempo para atingir as necessidades energéticas, adequação energética e proteica, déficit energético cumulativo, adequação da fórmula nutricional e períodos de jejum; ganho de peso, à ocorrência de enterocolite necrosante, à mortalidade e ao tempo de internação na unidade. Os dados foram analisados no Statistical Package for the Social Sciences a 5\% de significância.

\section{Resultados}

O tempo para início da nutrição enteral e as calorias infundidas $/ \mathrm{kg} /$ dia foram preditores do tempo de internação $F(2,46)=6,148 ; p=0,004 ; R 2=0,211$; assim como o déficit energético cumulativo + peso ao nascer + calorias infundidas/ $\mathrm{kg} / \mathrm{dia}\left(\mathrm{F}=3,52 ; p<0,001 ; R^{2}=0,422\right)$; déficit energético cumulativo + calorias infundidas/kg/dia + tempo de jejum de Nutrição Enteral ( $\left.F=15,041 ; p<0,001 ; R^{2}=0,474\right)$ foram preditores do ganho de peso. O tempo para início da nutrição enteral, a idade gestacional e o peso ao nascer estiveram inversamente associados à ocorrência da enterocolite necrosante $\beta=-0,38 ; \beta=-0,198 ; \beta=-0,002)$. A nutrição enteral precoce predispôs à mortalidade $(\beta=0,33)$. Estiveram inversamente relacionados à mortalidade, a idade gestacional, o peso ao nascer e as calorias infundidas $/ \mathrm{kg} / \mathrm{dia}$ $(\beta=-0,442 ; \beta=-0,004 ; \beta=-0,08)$.

\section{Conclusão}

Considerando-se as associações entre indicadores e desfechos, recomenda-se o monitoramento rotineiro do tempo para início da nutrição enteral; da adequação energética; do déficit energético e do tempo de jejum.

Palavras-chave: Indicadores de morbimortalidade. Enterocolite necrosante. Unidade de Terapia Intensiva Terapia Nutricional. Recém-nascido Prematuro.

\section{INTRODUCTION}

Achieving adequate growth and development in the Preterm Newborn (PTNB) is a challenge in neonatology due to the immaturity of the gastrointestinal tract, adaptive metabolic difficulties and clinical conditions, such as: breathing, eating problems, infections, jaundice, intraventricular hemorrhage, Necrotizing Enterocolitis (NEC), retinopathy and anemia of prematurity, persistence of the ductus arteriosus and metabolic bone disease [1-4].

It is common in the early life of premature infants not to be able to feed orally, requiring the use of alternative methods. Thus, enteral and/or parenteral nutritional therapy are routine in Neonatal Intensive Care Units (NICU) [5,6].

In a complex environment such as the NICU, carrying out Nutritional Therapy (NT) is an example of the difficulty in transforming evidence into practices and the growth restriction of newborns is one of the results of not implementing or following TN protocols [7]. This therapy can bring complications such as metabolic and/or gastrointestinal disorders, hyperglycemia, catheter infection, among others that need to be monitored through quality control in nutritional assistance [8]. To assess quality, indicators are used to measure the efficiency of nutritional support and develop an action plan to improve the quality of care [9]. 
Thus, the aim of this study was to associate Quality Indicators for Nutritional Therapy (QINT) - time to start feeding, volume infusion, calories and proteins, adequacy of the diet to the patient's needs and fasting time -, with pre-determined clinical outcomes, in a neonatal intensive care unit.

\section{METHODS}

Descriptive, prospective study, carried out in a public NICU, in the city of Palmas, Tocantins, Brazil. Data were collected through daily visits to the NICU between March 1, 2016 and September 1, 2016, in which the PTNB admitted to the unit during this period were monitored, until discharge or death. Data on admission and discharge from the NICU were retrieved from the medical records, as well as beginning and route of feeding; type and volume of enteral nutritional formula prescribed and infused; infusion rate; implementation time; time and reason for suspension of the diet; weight and daily medical evolution

Newborns with a gestational age of less than 37 weeks and submitted to Enteral Nutrition Therapy (ENT) or Parenteral Nutrition Therapy (PNT) were included. Preterm infants exclusively fed to the mother's breast and those transferred were excluded.

The sample size was calculated considering the prevalence of PTNB in the 20 beds of the unit, during the months of collection, with a 95\% confidence interval. The OpenEpi program, Version 3, was used, which estimated the sample by the formula: [EDFF*Np(1-p)]/[(d2/Z21- $\alpha / 2 *(N-1)+p *(1-p)]$, totaling 82 infants. All newborns who met the inclusion criteria were followed up. Gestational Age (GA), Birth Weight (BW), gender and date of birth were collected from the Statement of Live Births.

The classification of birth weight was carried out according to the World Health Organization (WHO) guidelines and weight for gestational age was assessed according to the curves proposed by Fentom and $\operatorname{Kim}[10,11]$. Weight measurement was performed daily. The energy and protein requirements were considered adequate when greater than or equal to $100 \mathrm{Kcal} / \mathrm{kg} / \mathrm{day}$ and equivalent to $3.0 \mathrm{~g}$ of protein $/ \mathrm{kg} /$ day respectively [12].

Among the existing QINT, those that met the characteristics of the population and that would allow collection were selected, according to the service routine, since the NICU in question did not have QINT under monitoring or protocols for the beginning and evolution of NT. They included: time to NT start - adequate when the number of hours between birth and the start of NT is less than 24 hours; energy and protein adequacy - adequate when the ratio between the average supply and the caloric-protein needs is $70 \%$ or more; Cumulative Energy Demand (CED) - adequate when non-existent from admission to discharge or death, including fasting periods; adequacy of formula infusion - adequate when the ratio between infused and prescribed volume is equal to or greater than $70 \%$; prolonged fasting - suitable when the fasting hours after starting NT are less than 24 continuous hours fasting. Such QINT were associated with the outcomes: weight gain, occurrence of NEC, mortality and length of hospital stay.

Data were evaluated using the SPSS statistical program, version 20.0 [13]. The QINT were considered predictive variables; for the validation of the statistical models, 2 or 3 independent variables were used, according to the $\mathrm{N}$ obtained after excluding the outliers. For all statistical tests performed, the significance level was set at $5 \%$. For outcomes which regression was not possible, Fischer's exact test was used as well as calculation of the Odds Ratio for the categorical variables.

Data regarding the variables with normal distribution are presented as means and standard deviations, and for the other variables the medians and confidence intervals $(95 \% \mathrm{CI})$ are shown. The experimental protocol was approved by the Human Research Ethics Committee of the Universidade Federal do Tocantins, under number 552015. 


\section{R E S U L T S}

A total of 104 premature infants were hospitalized during the period; 23 met the exclusion criteria. The final sample consisted of 81 PTNB (99\% of the sample calculation) with an average Gestational Age (GA) of 32.16 \pm 3.4 weeks, birth weight of $1,631 \pm 653.30 \mathrm{~g}$ and at discharge $1,752.44 \pm 637.99 \mathrm{~g}$.

There was a predominance of male PTNB, late preterm, with Low Weight (LW) at birth and with appropriate weight for GA as shown in Table 1. As to the most common clinical conditions, the presence of early neonatal sepsis, respiratory distress, need for invasive mechanical ventilation and use of vasoactive drugs ought to stand out.

Table 1 - Characterization of premature infants admitted to the Neonatal Intensive Care Units of a Public Maternity Hospital. Palmas (TO), 2016.

\begin{tabular}{|c|c|c|}
\hline \multirow{2}{*}{ Variable } & \multicolumn{2}{|c|}{ Values } \\
\hline & Mean & SD \\
\hline Gestational age at birth (weeks) $^{*}$ & 32.16 & 3.40 \\
\hline Gestational age at outcome (weeks) ${ }^{*}$ & 34.84 & 3.65 \\
\hline Weight at birth $(g)^{*}$ & $1,631.00$ & 653.30 \\
\hline \multirow[t]{2}{*}{ Weight at discharge $(\mathrm{g})^{*}$} & $1,752.44$ & 637.99 \\
\hline & $\%$ & $\mathrm{n}$ \\
\hline \multicolumn{3}{|l|}{ Gender } \\
\hline Male & 50.61 & 41 \\
\hline Female & 49.38 & 40 \\
\hline \multicolumn{3}{|l|}{ Preterm classification ${ }^{* *}$} \\
\hline Extreme preterm & 13.58 & 11 \\
\hline Very preterm & 24.69 & 20 \\
\hline Moderate preterm & 24.69 & 20 \\
\hline Late preterm & 37.04 & 30 \\
\hline Weight at birth classification ${ }^{* * *}$ & - & - \\
\hline Extreme Low Weight & 20.98 & 17 \\
\hline Very Low Weight & 25.92 & 21 \\
\hline Low Weight & 46.91 & 38 \\
\hline Insufficient Weight & 4.93 & 4 \\
\hline Normal weight & 1.23 & 1 \\
\hline \multicolumn{3}{|l|}{ Weight Classification for Gestational Age at Birth } \\
\hline Low for Gestational Age at Birth & 22.22 & 18 \\
\hline Adequate for Gestational Age at Birth & 75.30 & 61 \\
\hline High for Gestational Age at Birth & 2.46 & 2 \\
\hline \multicolumn{3}{|l|}{ Weight Classification for Gestational Age at Discharge } \\
\hline Sm Low all for Gestational Age at Discharge & 62.96 & 51 \\
\hline Adequate for Gestational Age at Discharge & 37.03 & 30 \\
\hline \multicolumn{3}{|l|}{ Prevalence of clinical conditions } \\
\hline Early sepsis & 86.42 & 70 \\
\hline Respiratory distress syndrome/ early respiratory distress & 81.48 & 66 \\
\hline Use of vasoactive drugs & 66.67 & 54 \\
\hline Invasive Mechanical Ventilation & 62.90 & 51 \\
\hline Glucose metabolism disorders & 23.46 & 19 \\
\hline Anemia & 18.82 & 15 \\
\hline Acute renal failure & 18.82 & 15 \\
\hline Septic shock & 14.81 & 12 \\
\hline
\end{tabular}

Note: "Mean and Standard Deviation; **World Health Organization [4]; ${ }^{* * *}$ World Health Organization [32]; SD: Standard Deviation. 
The mean hospital stay was $20.41 \pm 19.52$ days, the GA at discharge was $34.84 \pm 3.65$ weeks and the average weight gain was 0.00 (-2.96-3.42)g/day. Human Milk (HM) was a source of food for 73 PTNB (90.12\% of cases); however, in only 6 infants (8.22\%) HM was an exclusive source of food.

Considering the nutritional aspects, there was an average requirement of $180.81 \pm 77.91 \mathrm{Kcal} /$ day and $3.63 \pm 1.85 \mathrm{~g}$ of protein/day. The adequacy of the infused calories was $62.45 \pm 21.38 \%$; the adequacy of proteins was $65.41 \pm 26.26 \%$; the adequacy of the infused PN volume was $92.86(88.78-93.15) \%$ and of the infused enteral nutrition volume 98.83 (89.16-96.72)\%.

The CED was $640.17(871.49-1524.00) \mathrm{Kcal}$; the time to start the PNT was $46.75(49.35-64.55)$ hours and the ENT 41.00 (39.04-51.40) hours. The Total Fasting Time (TFT) of the PN was $0.00(15.15-84.21)$ hours and the EN 3.00 (30.63-78.78) hours.

The Table 2 shows the results of univariate analyses. The Time to Start Enteral Nutrition (TSEN), the calories infused per $\mathrm{kg}$ per day (Kcal/kg/day), the CED and the adequacy of the infused EN volume were associated with the length of stay in the NICU; while BW, Kcal/kg, CED and enteral nutrition TFT were associated with weight gain.

Table 2 - Univariate analysis of numerical indicators of nutritional therapy quality with length of stay at the Neonatal Intensive Care Units and weight gain, for premature newborns. Palmas (TO), 2016.

\begin{tabular}{|c|c|c|c|c|c|c|}
\hline \multirow{2}{*}{ Variables } & \multicolumn{3}{|c|}{ Length of hospital stay } & \multicolumn{3}{|c|}{ Weight gain } \\
\hline & $\mathrm{F}$ & $\mathrm{R} 2$ & $p^{*}$ & $\mathrm{~F}$ & $\mathrm{R} 2$ & $p^{*}$ \\
\hline Gestational age (weeks) & 1.216 & 0.024 & 0.276 & 2.923 & 0.043 & 0.092 \\
\hline Birth weight (g) & 0.049 & 0.001 & 0.826 & 4.206 & 0.064 & 0.045 \\
\hline Time to start PN (hours) & 0.083 & 0.002 & $0.775^{* *}$ & 2.011 & 0.032 & 0.161 \\
\hline Time to start of EN (hours) & 7.392 & 0.120 & 0.009 & 2.019 & 0.030 & 0.160 \\
\hline Infused calories by body weight (Kcal) & 7.763 & 0.142 & 0.008 & 6.270 & 0.088 & 0.015 \\
\hline Adequacy of infused calories (\%) & 1.185 & 0.021 & $0.281^{* *}$ & 1.027 & 0.016 & $0.315^{* *}$ \\
\hline Cumulative Energy Deficit (Kcal) & 9.369 & 0.148 & 0.003 & 15.495 & 0.217 & 0.000 \\
\hline Infused protein (g/day) & 0.881 & 0.016 & 0.352 & 0.146 & 0.002 & 0.704 \\
\hline Infused protein according to body weight (g) & 0.282 & 0.005 & 0.598 & 1.650 & 0.025 & 0.204 \\
\hline Adequacy of the infused protein (\%) & 0.173 & 0.003 & 0.679 & 1.654 & 0.025 & 0.203 \\
\hline Adequacy of the volume of PN infused (\%) & 0.262 & 0.007 & 0.612 & 0.210 & 0.004 & 0.649 \\
\hline Infused EN volume (mL) & 1.359 & 0.031 & 0.250 & 2.998 & 0.048 & 0.089 \\
\hline Adequacy of the infused EN volume (\%) & 6.979 & 0.149 & $0.012^{* *}$ & 0.429 & 0.007 & 0.515 \\
\hline Total of EN fasting time (hours) & 1.708 & 0.036 & 0.198 & 8.709 & 0.129 & $0.005^{* *}$ \\
\hline Total of PN fasting time (hours) & 0.042 & 0.001 & 0.839 & 0.983 & 0.018 & 0.326 \\
\hline
\end{tabular}

Note: "ANOVA; ${ }^{* *}$ Significant at a statistical level; EN: Enteral Nutrition; F: F- test; PN: Parenteral Nutritition; R2: R-Squared.

For the outcome length of stay, the TSEN model with $\mathrm{Kcal} / \mathrm{kg} /$ day was the only one that was significant $\left[F(2.46)=6.148 ; p=0.004 ; R^{2}=0.211\right] ; \operatorname{TSEN}(\beta=-0.265 ; p=0.05) ; \mathrm{Kcal} / \mathrm{Kg} /$ day $(\beta=0.341 ; p=0.013)$. The equation that describes the relationship is ICU Time $=7.384+(-0.029) \times T S E N+0.067 \times K \mathrm{Cal} / \mathrm{Kg} / \mathrm{day}$.

The weight gain outcome could be partially explained by the CED model with BW and $\mathrm{Kcal} / \mathrm{Kg} /$ day ( $\left.F=3.52 ; \quad p<0.001 ; R^{2}=0.422\right) ; \operatorname{CED}(\beta=0.437 ; \quad p<0.001) ; \quad B W(\beta=-0.306 ; \quad p=0.007) ; \mathrm{Kcal} / \mathrm{Kg} / \mathrm{day}$ $(\beta=0.361 ; p=0.002)$. The equation obtained from the model is: Weight gain $=-4.046+0.004 x(C E D)+-$ $0.004 x(B W)+0.127 x(K c a l / K g / d a y)$. The CED model with $\mathrm{Kcal} / \mathrm{Kg} /$ day and TFT was also significant ( $\mathrm{F}=15.041$; 
$\left.p<0.001 ; R^{2}=0.474\right)$, and the CED $(\beta=0.264 ; p=0.026), \mathrm{Kcal} / \mathrm{Kg} /$ day $(\beta=0.514 ; p<0.001)$, and TFT EN $(\beta=0.446 ; p=0.001)$. Described by the equation: Weight gain $=-17.046+0.002 \times(C E D)+0.209 \times(\mathrm{Kcal} / \mathrm{Kg} /$ day)+0.038x(TFTEN). As for NEC, Gestational Age at Birth (GAB) showed a direct association and the number of hours to start EN, GAB and BW showed an inverse association with its occurrence (Table 3 ).

Table 3 - Univariate analysis of nutritional therapy quality numerical indicators with the occurrence of necrotizing Enterocolitis and mortality, of premature newborns in the Neonatal Intensive Care Units. Palmas (TO), 2016.

\begin{tabular}{|c|c|c|c|c|c|c|}
\hline \multirow{2}{*}{ Variable/Indicator } & \multicolumn{3}{|c|}{ NEC } & \multicolumn{3}{|c|}{ Mortality } \\
\hline & $x^{2}$ & $p$ & $\mathrm{R}_{\text {Naglekerke }}^{2}$ & $x^{2}$ & $p$ & $\mathrm{R}^{2}{ }_{\text {Naglekerke }}$ \\
\hline Gestational age (weeks) & 14.752 & $0.039^{*}$ & 0.089 & 7.357 & $0.000^{*}$ & 0.410 \\
\hline Birth weight (g) & 16.034 & $0.042^{*}$ & 0.171 & 18.878 & $0.016^{*}$ & 0.511 \\
\hline Time to start of PN (hours) & 11.347 & 0.183 & 0.002 & 10.098 & 0.258 & 0.021 \\
\hline Time to start of EN (hours) & 15.006 & $0.049^{*}$ & 0.105 & 7.540 & $0.001^{*}$ & 0.203 \\
\hline Prescribed calories (Kcal/kg/day) & 4.839 & 0.775 & 0.027 & - & - & - \\
\hline Calories infused per $\mathrm{kg}$ of weight $(\mathrm{Kcal} / \mathrm{Kg} / \mathrm{dia})$ & 8.163 & 0.418 & 0.026 & 27.008 & $0.000^{*}$ & 0.442 \\
\hline
\end{tabular}

Note: *Significant at a statistical level; EN: Enteral Nutrition; NEC: Necrotizing Enterolocolitis; PN: Parenteral Nutrition.

In the binary logistic regression for NEC it was observed that the BW model with TSEN was significant $\left[X^{2}(2)=12.015 ; p=0.002 ; R^{2}{ }_{\text {Naglekerke }}=0.310\right] ; \quad B W \quad(O R=0.998 ; 95 \% C l: 0.996-1,00) ;$ TSEN (OR=0.958; $95 \% \mathrm{Cl}: 0.916-1.001)$, as well as the GAB model with TSEN $\left[X^{2}(2)=8.369 ; p=0.015 ; R^{2}{ }_{\text {Naglekerke }}=0.221\right] ; G A B$ (OR=0.775; 95\%Cl: 0.609-0.987); TSEN (OR=0.958; 95\%Cl: 0.914-1.004).

Gestational age at birth, BW, TSEN and $\mathrm{Kcal} / \mathrm{kg} /$ day were associated with the outcome mortality. Receiving early EN was a factor that predisposed the total population to mortality. Inversely associated with mortality were GAB, BW and the amount of calories infused per kg per day (Table 3). However, only the GAB model with $B W$ proved to be a significant predictor of mortality $\left[X^{2}(8)=21.904 ; p=0.005 ; R^{2}{ }_{\text {Naglekerke }}=0.512\right]$; $\mathrm{GAB}(\mathrm{OR}=0.961 ; 95 \% \mathrm{Cl}: 0.691-1.337)$ and $\mathrm{BW}(\mathrm{OR}=0.997 ; 95 \% \mathrm{Cl}: 0.994-0.999)$. The indicators related to PN were not predictive of outcomes in univariate analyses and, therefore, did not compose the statistical models.

For the categorical variables, which regression cannot be performed, the association was verified using the Fischer Exact test, with TSEN ( $p=0.041)$ being significant for the occurrence of NEC and the adequacy of the EN formula $(p=0.010)$ significant for mortality. The variables: time to reach caloric and protein needs, energy and protein adequacy, adequacy of energy and protein infusion, adequacy of enteral/ parenteral nutrition formula and fasting were not related to these outcomes ( $p>0.05$ ).

Prolonged enteral nutrition fasting was associated with greater chances of occurrence of NEC $(O R=1.417)$ and mortality $(O R=2.125)$.In the total sample, the occurrence of NEC was $8.64 \%(n=7)$, mortality $20.98 \%(n=17)$; a total of $64.20 \%(n=52)$ were discharged into the care of the Intermediate Care Unit, $7.40 \%(n=6)$ were transferred to another hospital unit and $7.40 \%(n=6)$ were discharged home.

\section{DISCUSSION}

The results of this study call attention to common failures that compromise nutritional therapy, such as the delay in the beginning of feeding, inadequate caloric-protein supply and the nutrition volume offered. Among the quality indicators, those directly related to these variables were positively associated with the outcomes assessed. 
We observed an inverse association between the time to start enteral nutrition and the stay in the NICU, contradicting the current recommendations $[2,14,15]$. Early EN was associated with NEC, in line with the work of Modi et al. [16], where aggressive early feeding in infants with very low birth weight increased the risk of food intolerance and NEC. Our data corroborate with the literature in the sense that NEC hardly develops before the supply of food, via the gastrointestinal tract, and the use of this route and formula poses a risk for its development $[3,4,17]$. Other factors that can contribute to the emergence of NEC are the presence of sepsis, common in our population, and the absence of HM feeding $[17,18]$.

Recommendations to start feeding between $24-72 \mathrm{~h}$ of life in small amounts ( $<24 \mathrm{~mL} / \mathrm{kg} /$ day) for 3 to 5 days, aim to ensure the maturation of the gastrointestinal tract and reduce mucosal atrophy, infections and the time to reach a full diet, avoiding the development of complications in connection with NT $[19,20,21]$. Therefore, the early start of nutrition must be trophic and follow strict parameters for evolution; however, in the unit studied the lack of protocols did not ensure these steps, and may have contributed to the association found between the time to start enteral nutrition and the stay at the NICU and NEC.

Still with respect to ENT, we found that the lower the percentage of adequacy of the formula infused, the longer the infant's stay in the NICU, and the longer it takes to reach the minimum weight for discharge. EN, especially in preterm infants with very low birth weight, is commonly postponed due to cardiorespiratory complications and concerns about NEC. The high prevalence of infants with respiratory failure in our population and the lack of protocols for diet infusion are factors that negatively influenced weight gain, thus delaying discharge. In addition, it is noteworthy that the adequacy of the diet infusion was greater than $90 \%$ of the prescribed volume, but the adequacy of calories and proteins was below $70 \%$, signaling an underestimation of the caloric-protein needs.

The population's weight gain can be strongly explained by two models that combine DEC, BW, $\mathrm{Kcal} / \mathrm{kg} /$ day and TFT. In both models, the CED variable stood out as a main cause and as a strong predictor of weight gain, as sustained by Abranches et al. [22], who affirm that the daily nutrients deficit, caused by the inadequate amount of infused energy, predisposes the newborn to low weight gain, reflected in the newborn anthropometric parameters.

The length of stay was related to the TSEN and $\mathrm{Kcal} / \mathrm{kg} /$ day indicators, with this model explaining $21.1 \%$ of the length of stay in the unit studied. As already mentioned, the time to start the diet in this study was in conflict with the literature. An interval of $17.7 \mathrm{~h}$ to $20.4 \mathrm{~h}$ is observed for infants with BW of approximately $1,000 \mathrm{~g}$ to start PN, in addition to 2.3 days for the beginning of the ENT $[23,24]$. For infants under 1,250g, Jeong et al. [25] recommend the infusion of glucose and protein in the first 24 hours of admission and the beginning of EN between $6.4 \pm 5.8$ days and an average protein infusion of $2.0 \mathrm{~g} / \mathrm{kg} /$ day in the first week.

The median time to onset of PN in our study was 46.75 hours, longer than recommended and in line with the results of Freitas et al. [26] who found onset of PNT on average on the third day of life, showing the difficulty of adapting the protocols in the clinical routine. Postponing the beginning of NT beyond the periods established in the guidelines can lead to malnutrition, increasing susceptibility of the patient to infections and postoperative complications compromising the patient's clinical response [9].

In our study, the length of stay in the ICU was associated only with the beginning of EN and the amount of calories, contradicting the strong association with weight described by Lee et al. [27]. The shortening of the length of stay in the NICU represents a lower risk of infections, an improvement in the patient's quality of life, the mother's competence in caring for her child, early family integration and a reduction in the health service costs [28]. It is observed that hospitalization for extended periods tends to 
trigger high levels of stress, depression and anxiety in parents, fear, difficulties in reconciling work and other infants with visits to the NICU, in addition to fear due to the possibility of death; therefore, all possible efforts should be implemented to reduce the permanence of infants in the NICU [29].

We observed that the occurrence of NEC was better explained when TSEN and BW were combined, with BW $(O R=0.998)$ and $G A B(O R=0.775)$ being protective factors. The 7 cases of NEC in this study were diagnosed in infants who received exclusive NPT, with a formula based on amino acids, glucose and lipids for a period of 5 to 12 days after birth; HM was introduced in the first 24 hours of hemodynamic stability, and subsequently replaced by an extensively or fully hydrolyzed formula. Out of these cases of NEC, $85.7 \%$ were diagnosed in infants weighing $<1.5 \mathrm{~kg}$.

Necrotizing enterocolitis is the cause of $10 \%$ of all deaths in the NICU; it occurs in $7 \%$ of PTNB, and can reach 10 or $11 \%$ in those born with very low birth weight, prematurity being the greatest and most frequent risk factor for NEC; the greater the number of very low birth weight or extremely low birth weight infants, the greater the frequency of NEC. It is known that the occurrence of this disease is associated with sepsis, hypothermia, congenital heart disease, fasting and the absence of HM feeding, use of food formula, blood transfusion and bacterial colonization [18,30].

Among the selected QINTS that showed to be predictors of mortality, the time to start enteral nutrition, Kcal/kg/day, birth weight and gestational age, the past two also being reported in mortality predictive models in an 8-year follow-up cohort [31]. In that cohort with data from 88,327 preterm infants with BW $<1.5 \mathrm{~kg}$, the mortality rate ranged from 7 to $22 \%$ and was inversely proportional to GA; infants born at 24 weeks had a mortality rate of $35 \%$ to $51 \%$ while those born at 29 weeks had a mortality rate of $8 \%[31,32]$. Another study of 7,606 premature infants showed that $32 \%$ died and that the risk factors were very low birth weight, extreme prematurity and hemodynamic disorders [33].

Freitas [34] followed 239 premature infants admitted to the NICU and found a death rate lower than ours (13.3\%), as well as a lower number of discharges to other hospital's units (44.4\%) and home discharge happened in $27.3 \%$ of cases. Perhaps the best prognosis found by Freitas [33] can be attributed to the better weight evolution (initial weight $1,712 \pm 684 \mathrm{~g}$ and final weight $2,209 \pm 479 \mathrm{~g}$ ), while in our study the difference was only $121 \mathrm{~g}$ between the birth weight and discharge averages. The insufficient weight gain that we found 0.00 (95\% Cl-2.96-3.42g/day) can be explained by the inadequacy of caloric and protein infusions that met on average only $67.31 \%$ and $65.41 \%$ of the infant's needs, respectively.

\section{CONCLUSION}

The present work points to the use of quality indicators in NT, as instruments for technique improvement, monitoring and standardization in the NICU. The decision on the QINTs to be adopted depends on the recommended outcomes. According to the associations obtained between indicators and outcomes, routine monitoring of time to start nutritional therapy is recommended, as well as Energy adequacy; cumulative energy demand and fasting periods.

In addition to the implementation of QINT, this study suggests that the use of protocols for the initiation and evolution of nutrition are crucial for the success of nutritional therapy. It is necessary to further studies on the subject, since the sample size made it impossible to carry out all the necessary regression analyses in this study. 


\section{ACKNOWLEDGMENTS}

We are grateful for the collaboration and welcome of the team of professionals from the NICU of the Hospital where the study data were collected.

\section{CONTRIBUTORS}

LC HOLZBACH contributed whit the conception, design, investigation, data interpretation and editor. RJ PEREIRA contributed whit the guidance, data interpretation, review and final approval. RAM Moreira contributed whit the statistical analysis, data interpretation and final approval.

\section{RE FER E N C E S}

1. Koletzko B, Poindexter B, Uauy R. Nutritional care of preterm infants. World Rev Nutr Diet. 2014;110:253-63. https://doi.org/10.1159/000358474

2. Feferbaum R, Falcão MC, Schimider KF, Barros K. Recomendações nutricionais para prematuros e/ou recém-nascidos de muito baixo peso. São Paulo: International Life Sciences Institute of Brasil; 2016 [citado 2020 Jan 15]. Disponível em: http://ilsibrasil.org/wp-content/uploads/sites/9/2016/08/VERS\%C3\%830-ONLINE-Recomendacoes-Nutricionaispara-Prematuros-e-ou-recem-nasc.pdf

3. Euclydes M. Nutrição do lactente: bases científicas para uma alimentação saudável. 4a. ed. Viçosa: Universidade Federal de Viçosa; 2014.

4. World Health Organization. Born too soon: the global action report on preterm birth. Geneva: Organization; 2012 [cited 2020 Jan 15]. Available from: https://apps.who.int/iris/bitstream/handle/10665/44864/9789241503433_eng. pdf;jsessionid=4A66412844323D2517EBBFC59EF66406 ? sequence=1.

5. Lima AH, Côrtes MG, Bouzada MCF, Friche AAL. Prontidão do recém-nascido prematuro para a alimentação oral: revisão sistemática e metanálise. Codas. 2015;27(1):101-7. https://doi.org/10.1590/2317-1782/20152014104

6. Pagliaro $\mathrm{CL}$, Bühler KEB, Ibidi SM, Limongi SCO. Dietary transition difficulties in preterm infants: critical literature review. J Pediatr. 2016;92(1):7-14. https://doi.org/10.1016/j.jpedp.2015.11.001

7. Johnson MJ, Leaf AA, Pearson F, Clark HW, Dimitrov BD, Pope C, et al. Successfully implementing and embedding guidelines to improve the nutrition and growth of preterm infants in neonatal intensive care: a prospective interventional study. Br Med J Open.2017;7:e017727. https://doi.org/10.1136/bmjopen-2017-017727

8. Oliveira-Filho RS, Ribeiro LMK, Caruso L, Lima PA, Damasceno NRT, Soriano FG. Quality indicators for enteral and parenteral nutrition therapy: application in critically ill patients 'at nutritional risk'. Nutr Hosp. 2016:33:1027-35. https://doi.org/10.20960/nh.563

9. Shiroma GM, Horie LM, Castro MG, Martins JR, Bittencourt AF, Logullo L, et al. Nutrition quality control in the prescription and administration of parenteral nutrition therapy for hospitalized patients. Nutr Clin Pract. 2015;30:406-13. https://doi.org/10.1177/0884533614567540

10. World Health Organization. ICD-10: International Statistical Classification of diseases and relates health problems. 2nd ed. Geneva: World Health Organization; 2004 [cited 2019 Dec 10]. Available from: https://apps.who.int/iris/ bitstream/handle/10665/42980/9241546530_eng.pdf?sequence=1\&isAllowed=y

11. Fenton TR, Nasser R, Eliasziw M, Kim JH, Bilan D, Sauve R. Validating the weight gain of preterm infants between the reference growth curve of the fetus and the term infant. Bmc Pediatr. 2013;13(1):1-10.

12. Falcão MC, Buzzini R. Terapia nutricional no prematuro extremo. Brasília: Conselho Federal de Medicina; $2011: 1-8$.

13. International Business Machines Corporation. Statistical Package for the Social Sciences: Statistical Software. São Paulo: IBM; 2020.

14. Nangia S, Vadivel V, Thukral A, Saili A. Early total enteral feeding versus conventional enteral feeding in stable very-low-birth-weight infants: a randomised controlled trial. Neonatology. 2019;115:256-62. https://doi. org/10.1159/000496015

15. Baylor College of Medicine. Guidelines for acute care of the neonate. 26. ed. Houston: Baylor College of Medicine; 2016 [cited 2020 Jan 20]. Available from: https://relaped.com/wp-content/uploads/2018/08/Guidelines-for-AcuteCare-of-the-Neonate_2018.pdf 
16. Modi M, Ramji S, Jain A, Kumar P, Gupta N. Early aggressive enteral feeding in neonates weighing 750-1250 grams: a randomized controlled trial. Indian Pediatr. 2019[cited 2020 Aug 12];56:294-8. Available from: https://www. indianpediatrics.net/apr2019/294.pdf

17. Patel AL, Kim JH. Human milk and necrotizing enterocolitis. Semin Pediatr Surg. 2018;27:34-8. https://doi. org/10.1053/j.sempedsurg.2017.11.007

18. Rich BS, Dolgin SE. Necrotizing enterocolitis. Pediatr Rev. 2017;38:552-9. https://doi.org/10.1542/pir.2017-0002

19. Brennan AM, Murphy BP, Kiely ME. Optimising preterm nutrition: present and future. Proc Nutr Soc. 2016;75:154-61. https://doi.org/10.1017/S0029665116000136

20. Salas AA, Kabani N, Travers CP, Philips V, Ambalavanan N, Carlo WA. Short versus extended duration of trophic feeding to reduce time to achieve full enteral feeding in extremely preterm infants: an observational study. Neonatology. 2017;112:211-6. https://doi.org/10.1159/000472247

21. Lima AM, Goulart AL, Bortoluzzo AB, Kopelman BI. Nutritional practices and postnatal growth restriction in preterm newborns. Rev Assoc Med Bras. 2015;61:500-6. https://doi.org/10.1590/1806-9282.61.06.500

22. Abranches AD, Soares FVM, Villela LD, Méio MDBB, Zin AO, Junior SG, et al. Energy expenditure, growth, and nutritional therapy in appropriate and small for gestational age preterm infants. J Pediatr. 2018;94:652-7. https:// doi.org/10.1016/j.jped.2017.09.005

23. Uthaya S, Liu X, Babalis D, Doré CJ, Warwick J, Bell J, et al. Nutritional evaluation and optimisation in neonates: a randomized, double-blind controlled trial of amino acid regimen and intravenous lipid composition in preterm parenteral nutrition. Am J Clin Nutr. 2016;103:1443-52.https://doi.org/10.3945/ajcn.115.125138

24. Marcuartú A, Malveira S. Perfil de recém-nascidos prematuros de muito baixo peso internados em unidade de cuidados intensivos neonatais. Rev Bras Ciênc Saúde. 2017;21:5-10. https://doi.org/10.22478/ufpb.2317$6032.2017 \mathrm{v} 21 \mathrm{n} 1.28551$

25. Jeong E, Jung YH, Shin SH, Kim MJ, Bae HJ, Cho YS, et al. The successful accomplishment of nutritional and clinical outcomes via the implementation of a multidisciplinary nutrition support team in the neonatal intensive care unit. Bmc Pediatr. 2016;16:1-6. https://doi.org/10.1186/s12887-016-0648-0

26. Freitas BAC, Priore SE, Lima LM, Franceschini SCC. Extrauterine growth restriction: universal problem among premature infants. Rev Nutr. 2016;29:53-64. https://doi.org/10.1590/1678-98652016000100006

27. Lee HC, Bennett MV, Schulman J, Gould JB, Profit J. Estimating length of stay by patient type in the neonatal intensive care unit. Am J Perinatol. 2016;33:751-7. https://doi.org/10.1055/s-0036-1572433

28. Miltersteiner AR, Molle LD, Claus SM, Rotta NT. Tempo de internação hospitalar de bebês pré- termos observados na posição mãe-canguru e na posição prona na incubadora. Rev AMRIGS. 2005 [citado 10 jan 2020];49:20-6. Disponível em: https://www.amrigs.org.br/revista/49-01/ao03.pdf\#gsc.tab=0

29. Pineda R, Bender J, Hall B, Shabosky L, Annecca A, Smith J. Parent participation in the neonatal intensive care unit: predictors and relationships to neurobehavior and developmental outcomes. Early Hum Dev. 2018;117:32-8. https:// doi.org/10.1016/j.earlhumdev.2017.12.008

30. Arbra CA, Oprisan A, Wilson DA, Ryan RM, Lesher A. Time to reintroduction of feeding in infants with nonsurgical necrotizing enterocolitis. J Pediatr Surg. 2018;53:1187-91. https://doi.org/10.1016/j.jpedsurg.2018.02.082

31. Helenius K, Sjörs G, Shah PS, Modi N, Reichman B, Morisaki N. Survival in very preterm infants: an international comparison of 10 national neonatal networks. Obstet Gynecol Surv. 2018;73:187-9. https://doi.org/10.1542/ peds.2017-1264

32. Stoll BJ, Hansen NI, Bell EF, Walsh MC, Carlo WA, Shankaran S, et al. Trends in care practices, morbidity, and mortality of extremely preterm neonates, 1993-2012. Jama. 2015;314(10):1039-51. https://doi.org/10.1001/jama.2015.10244

33. Bezzine A, Chebbi I, Hamida EB, Zahra Marrakchi Z. Mortalité intra-hospitalière des grands prématurés dans un centre de soins intensifs néonatals Tunisien: prévalence et facteurs de risqué. Tunis Med. Epub ahead print. 2018;[cited 2020 aug 11];16:884-7. Available from: http://latunisiemedicale.com/m/article-medicale-tunisie_3478_fr

34. Freitas BAC. Parâmetros clínicos, epidemiológicos e nutricionais de recém-nascidos prematuros atendidos em uma Unidade de Terapia Intensiva neonatal no município de Viçosa-MG [tese]. Viçosa: Universidade Federal de Viçosa; 2011 [citado 15 ago 2020]. Disponível em: https://www.locus.ufv.br/handle/123456789/2753 